\title{
Kişilerarası Duygu Düzenleme Yaklaşımına Dayalı Geliştirilen Grup Psikoeğitim Programının Üniversite Öğrencilerinin Kişilerarası Duygu Düzenleme Becerilerine Etkisi ${ }^{1}$
}

\section{The Effect of Group Psychoeducation Program Based on Interpersonal Emotion Regulation Approach on Interpersonal Emotion Regulation Skills of University Students}

\begin{tabular}{|c|c|}
\hline & Ayşe Özlem SARICAOĞLU² Raşit AVCI $^{3}$ \\
\hline $\begin{array}{l}\text { Anahtar Kelimeler } \\
\text { Kişilerarası duygu } \\
\text { düzenleme, } \\
\text { psikoeğitim, } \\
\text { beceri ĕgitimi. }\end{array}$ & 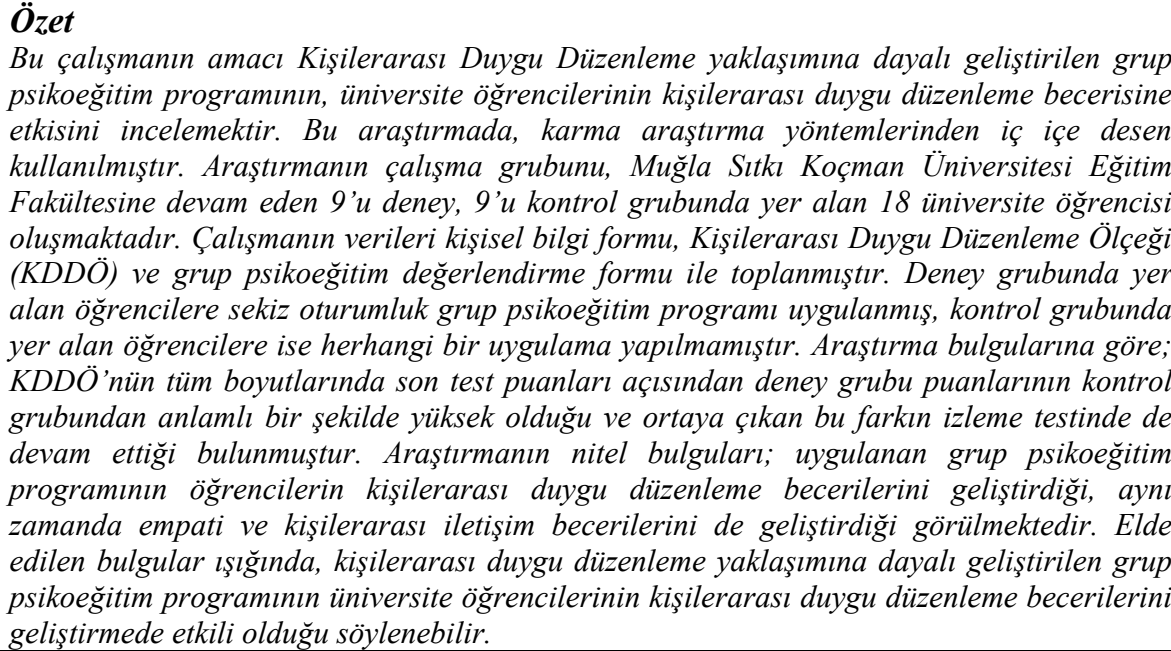 \\
\hline
\end{tabular}

\section{Abstract}

The aim of this study is to investigate the effect of group psychoeducation program based on Interpersonal Emotion Regulation approach on interpersonal emotion regulation skills of university students. In this study, embedded design, one of the mixed research methods, was

$\underline{\text { Key Word }}$ Interpersonal emotion regulation, psychoeducation, skills training. used. The study group consisted 18 university students: 9 in the experimental group and 9 in the control group. The data of the study were collected through personal information form, Interpersonal Emotion Regulation Scale (IERS) and group psychoeducation evaluation form. Eight-session group psychoeducation program was applied to the students in the experimental group and no intervention was made to the students in the control group. The findings of the study showed that the scores of the experimental group were significantly higher than the control group in terms of post-test scores from all dimensions of the IERS. This effect is long-term in the experimental group. The qualitative findings of the study show that the applied group psychoeducation program improves the students' interpersonal emotion regulation skills, as well as empathy and interpersonal communication skills. According to the findings, it can be said that the group psychoeducation program developed based on the interpersonal emotion regulation approach is effective in developing the interpersonal emotion regulation skills of university students.

\begin{tabular}{|c|c|}
\hline $\begin{array}{l}\text { Atıf için: } \\
\text { For Citation }\end{array}$ & $\begin{array}{l}\text { Sarıcaoğlu, A. Ö. \& Avc1, R. (2021). Kişilerarası duygu düzenleme yaklaşımına dayalı } \\
\text { geliştirilen grup psikoeğitim programının üniversite öğrencilerinin kişilerarası duygu } \\
\text { düzenleme becerilerine etkisi. Muğla Sitkı Koçman Üniversitesi Eğitim Fakültesi [MSKU } \\
\text { Journal of Education], 8(1), 214-230. DOI: 10.21666/muefd.789210 }\end{array}$ \\
\hline & Published:01.05.2021 \\
\hline
\end{tabular}

\footnotetext{
${ }^{1}$ Bu çallşma Düzce Üniversitesi tarafindan 24-26 Haziran 2020 tarihlerinde düzenlenen "I. International Congress of Pedagogical Research" kongresinde sözlü/sanal bildiri olarak sunulmuş ve özet olarak yayımlanmiştır.

${ }^{2}$ MEB, aozlemsaricaoglu@gmail.com,ORCID:0000-0002-5951-1740

${ }^{3}$ Muğla Sitkı Koçman Üniversitesi, rasitavci@gmail.com, ORCID: 0000-0003-4947-3397
} 
Duygular insan hayatında önemli bir yere sahiptir. Bireyin yaşadığı duygu; mutluluk, neşe, aşk, gibi olumlu duyguları içerebildiği gibi hüzün, çaresizlik, üzüntü gibi olumsuz duyguları da içerebilir (Preece, Becerra, Robinson, Dandy ve Allan, 2018). Duygu, çok boyutlu yapısından dolayı tanımlanması ve değerlendirilmesi güç ve en karmaşık konulardan biridir (Leahy, Tirch ve Napolitano, 2011). Greenberg (2004) duyguların, bireyi ve çevresinde olan biteni anlamlandırmasına yardımcı olduğunu, bireyin yaşamına anlam kattığını; pişmanlık, hüzün, öfke, kaygı gibi olumsuz duyguların dahi bir bütün halinde bireyin iyilik haline katkıda bulunduğunu ifade etmiştir. Ayrıca ihtiyaçlar ve yaşamın gereklilikleri karşısında duygu düzenlemenin yapılamaması da bireyde sosyal ve duygusal bozukluklarına yol açabilmektedir (Preece vd., 2018). Çelik ve Kocabıyık (2014) tarafindan üniversite öğrencileri üzerinde gerçekleştirilen bir çalışmada, fiziksel saldırganlık ile bilişsel duygu düzenlemenin plana tekrar odaklanma ve pozitif yeniden gözden geçirme arasında negatif yönde, yıkım ve diğerlerini suçlama arasında pozitif yönde ilişkilerin olduğu bildirilmiştir. İşgören (2018) de bilişsel duygu düzenleme stratejileri ile depresyon arasında ilişkiler olduğunu ortaya koymuştur. Bireylerin kişilerarası ilişkilerde duygu düzenleme becerilerine sahip olması, onların iyilik hallerini yükseltirken, uygun olmayan duygu düzenleme; düşük iyilik hali ve somatik rahatsızlıklara neden olabilir. $\mathrm{Bu}$ yönüyle duygu düzenlemenin uyum sağlayıcı bir özelliği olduğu söylenebilir (Gross ve John, 2003). Bireylerin sosyal yaşamlarındaki uyumlarını koruyabilmeleri, güçlendirmeleri veya devam ettirebilmeleri için sahip oldukları duyguları nasıl yaşadıkları, ifade ettikleri ve yönettikleri önemlidir. $\mathrm{Bu}$ bağlamda duygu düzenleme üniversite öğrencilerinin yaşamlarında önemli bir kavramdır ve öğrencilerin uyum davranışlarıyla da ilişkili olduğu görülmektedir.

Duygu düzenleme becerisi bireyin duygusunun yoğunluğunu ayarlayabilmesi olarak değerlendirilebilir. Duygular ele alınırken önemli olan yaşanılan duygu yoğunluğunun nasıl yönetildiği yani duygu düzenleme sürecidir. Duygu düzenleme, bireylerin hangi duygulara sahip olduğunu, bu duyguları yaşama ve ifade etme biçimlerini içeren, duygusal durumları yönetmek için kullandıkları etkin bir süreçtir. Duygu düzenleme kavramı, alan yazında başlangıçta olumsuz duyguların kontrol edilmesi veya değiştirilmesi şeklinde ele alınsa da zamanla yeni çalışma ve araştırmalarla olumlu duyguların da düzenlenebilmesi olarak anlaşılmaya başlanmışıtır (Gross, 1999). Duygu düzenleme belirli bir duyguyu azaltmak, arttırmak ya da devam ettirmek için otomatik ya da kontrollü olabildiği gibi bilinçli veya bilinçdışı da gerçekleşen bir eylemdir (Gross ve Thompson, 2007). Duygular yoğun bir şekilde yaşandığında veya hissedilen duygu uygun şekilde ifade edilmediğinde bu durum bireyleri sıkıntıya sokabilmektedir (Ekman, Friesen ve Ellsworth, 2013). Duygu düzenleme öğrenme süreçleri yoluyla kazandırılabilen becerilerden biridir. Bu bağlamda duygu düzenleme becerisi çeşitli eğitimler aracılığıyla öğrenilmekte ve geliştirilebilmektedir.

Alan yazın inceldiğinde üniversite öğrencilerinin duygu düzenleme becerilerini geliştirmeye yönelik pek çok deneysel çalışmanın gerçekleştirildiği görülmektedir. Bu bağlamda Kuzucu (2006), duyguları fark etmeye ve ifade etmeye yönelik hazırladığı psiko-eğitim programının üniversite öğrencilerinin duygusal farkındalık düzeylerine, duyguları ifade etme eğilimlerine, psikolojik ve öznel iyi-oluşlarını artırmaya yönelik tek başına yeterli olmadığını ortaya koymuştur. Gülgez ve Gündüz (2015), duygu düzenleme becerileri yetersiz olduğu tespit edilen 18 üniversite öğrencisi üzerinde Diyalektik Davranış Terapisi temelli sekiz oturumluk bir duygu düzenleme programı uygulamış; bu programın bireylerin duygu düzenleme güçlüklerini azaltmada etkili olduğunu ortaya koymuşlardır. Demir ve Gündoğan (2018) bilinçli farkındalık yaklaşımı temelli bilişsel terapi programının psikoloji öğrenimi gören üniversite öğrencileri üzerinde etkililiğini sınamışlardır. Araştırma sonuçları programın öğrencilerin duygu düzenleme güçlüklerini azaltmada etkili olduğunu göstermiştir. Vatan (2020) sekiz üniversite öğrencisi üzerinde duygu düzenleme eğitiminin etkililiğini incelemiş ve programın öğrencilerin duygu düzenleme becerilerini güçlendirmede etkili olduğu ortaya koymuştur. Yapılan çalışmalarda öğrencilerin duygu düzenleme becerilerini geliştirmeye yönelik farklı kuramsal yaklaşımlara dayalı programlar hazırlandığı ve etkililiğinin incelendiği görülmektedir. Çelik ve Kocabıyık (2014) üniversite öğrencilerinde duygu düzenleme becerisinin kazandırılmasına yönelik psikoeğitim programları hazırlanmasının önemli olduğu vurgulanmaktadır (Çelik ve Kocabıyık, 2014). Bu çalışma kapsamında da üniversite öğrencilerinin kişilerarası duygu düzenleme becerilerini arttırmaya yönelik kişilerarası duygu düzenleme yaklaşımı temelli bir grup psikoeğitim programı hazırlanmıştır.

İnsanların duygularını nasıl düzenledikleri birçok araştırmacının ilgisini çekmiş ve duyguların nasıl düzenleneceği ile ilgili pek çok sınıflandırma yapılmıştır. Gross (1998) duygunun; durumun seçilmesi, durumun değiştirilmesi, dikkatin yayılması, bilişlerin değişimi ve tepkilerin ayarlanması olarak beş 
şekilde düzenlenebileceğini, Greenberg (2004) ise insanların duygularını; (1) maruz kaldıkları durumu yönetme, (2) durumu yeniden gözden geçirerek tepkilerini değiştirme veya bastırma ve (3) pekiştirme olarak üç şekilde düzenleyebildiklerini, vurgulamıştır. Linehan (1993) ise, duyguları tanımlama ve etiketlemenin, duygulara izin vermenin ve onları kabul etmenin, olumsuz duygulara karşı savunmayı azaltmanın, duygularla araya bir mesafe koymanın, olumlu duyguları artırmanın, kendi kendini yatıştırmanın, nefes almanın ve dikkati dağıtmanın duygusal güçlüklere yardımcı olduğunu ortaya koymuştur. Monat ve Lazarus (1991) da duygu düzenlemenin bir parçası olarak başa çıkma stratejilerini ele almış ve başa çıkmayı; problem odaklı ve duygu odaklı başa çıkma olarak sınıflandırmıştır. Lazarus'a (1993) göre başa çıkma; birey çevre etkileşiminde duyguları şekillendirmekte ve problem odaklı başa çıkma ile sıkıntı verici durumun ele alındığını, duygu odaklı başa çıkma ile duyguların düzenlendiğini belirtmektedir. $\mathrm{Bu}$ çerçevede düşünüldügünde, bireyin duygularını fark edebilmesi, kişilerarası ilişkilerde ifade edebilmesi ve dolayısıyla duygularını yönetebilmesi daha da önemli hale gelmektedir. Markus ve Kitayama'ya (1991) göre; bireyin ilişkilerini sürdürüp uyumlu bir sosyal etkileşimi koruması için diğer bireylerin nasıl hissettiklerini, nasıl düşündüklerini ve ilişkilerinde ne gibi davranışlarda bulunabileceklerini anlaması kişilerarası ilişkilerini yönetebilmesi için bir gerekliliktir. Duygu düzenleme adı verilen bu süreç, bireylerin amaçlarına ulaşabilmesi için duygusal tepkilerini düzenleyebilmesi, değerlendirebilmesi ve ayarlayabilmesini içeren tüm içsel ve dışsal süreçleri barındırmaktadır (Thompson, 1994).Duygu düzenleme araştırmaları genel olarak bireylerin bu süreci kendi içlerinde nasıl yürüttüklerini ve yönettiklerini incelemektedir (Gross ve Thompson 2007; Gross ve John, 2003; Greenberg, 2004). Duygu düzenleme kuramları ve araştırmaları hakkındaki alan yazın oldukça geniş ve köklü olmasına; konu üzerine hem betimsel hem de deneysel çalışmalar olmasına rağmen, duygu düzenlemenin kişilerarası yönü ve duyguların iletişimsel işlevi bu zamana kadar ihmal edilmiştir (Zaki ve Williams, 2013; Hofmann, Carpenter ve Curtiss, 2016). Esasında duygu düzenleme kavramını ilk ele alanlardan biri olan Thompson (1994) duyguların sadece kendi kendini düzenleme stratejileriyle (içsel) değil, aynı zamanda diğer insanları da içeren kişilerarası (dışsal) süreçlerle değiştirilebileceğini ifade etmiştir. Duygular, insanlardan bağımsız, yalıtılmış bir şekilde düzenlenmez tam tersine yaşam boyunca bireyi çevreleyen önemli sosyal ağlarla ve sosyal etkileşim içinde duygu düzenleme süreci gerçekleşmektedir. Kişilerarası duygu düzenleme sosyal ilişkilerin, duyguları deneyimleme ve ifade etmedeki önemini vurgulamaktadır. Kişilerarası duygu düzenleme modeli duyguların sosyal bir bağlamda gerçekleştiğini ve kısmen diğer insanlar tarafından düzenlendiğini öne sürmektedir (Hofmann, 2014). Kişilerarası süreçler, yaşam boyunca duygu düzenlemede kritik yapı taşıdır. Bireyler diğer insanların desteğini; stresi azaltmak, pozitif duyguları arttırmak ve zor zamanlarda diğer insanların varlıklarından yararlanmak için bir kaynak olarak görürler. Bu çabaların tamamlanması, bireyleri empatik, destekleyici, olumlu sosyal davranışlara ve diğer insanların duygularını düzenlemeye sevk etmektedir. (Zaki ve Williams, 2013; Hofmann, 2014). İnsanlarla etkileşim içsel ve kişilerarası süreçleri aynı anda içeren karmaşık bir özelliğe sahiptir. Zaki ve Williams (2013), bireylerin kendisinin ya da başkalarının duygularını düzenlerken hangi kişilerarası durumlara göre hangi düzenleme stratejilerini kullandığını belirlemeye çalışmışlardır. Ortaya koydukları bu modele göre, herhangi bir duygu düzenleme stratejisinin kişilerarası olarak kabul edilebilmesi için, aktif bir sosyal etkileşim bağlamında gerçekleşmesi ve düzenleyici amaçtan sonraki çabayı da göstermesi gerekmektedir.

Bilim insanları yıllar boyunca duygu düzenlemenin yalnızca içsel boyutunu farklı yaklaşımlarla ve çeşitli sınıflamalarla ele almışlardır. Benzer şekilde kişilerarası duygu düzenlemenin de sosyal destek alma ve sağlama, duygusal durumların paylaşımı, diğer insanların duygusal durumlarını geliştirmeye yardımcı olma gibi bazı yönleri üzerinde çalışmalar yapılmış ancak bu olgu, kavramsal üst bir yapı olarak yakın zamanda bir araya getirilmiş ve üzerine araştırmalar yapılmaya başlanmıştır (Hofmann, 2014; Zaki ve Williams, 2013). Alan yazında kişilerarası duygu düzenleme kavramı pek çok betimsel çalışmaya konu olmuş ve bu çalışmalarda duygu durum ve anksiyete bozukluğu, sosyal destek, depresyon, sosyal kaygı, bağlanma stilleri ve evlilik uyumu, yakın ilişkiler gibi kavramlarla ilişkiler incelenmiştir (Hofmann, 2014; Marroquin, 2011; Debrot, Schoebi, Perrez ve Horn, 2013; Karasu, 2020, Tarımtay, 2017; Uyarağalar, 2019). Ayrıca Türkiye'de bu kavramsal model ile ilgili olarak sadece ölçme aracı uyarlama çalışmaları (Koç, 2017; Gökdağ, Sorias, Kıran ve Ger 2019; Saruhan, Başman ve Ekşi, 2019; Sarıcaoğlu, 2020) gerçekleştirilmiştir. Alan yazında bu kuramsal modele dayalı herhangi bir deneysel müdahale programı araştırmasının yürütülmediği görülmektedir. 
$\mathrm{Bu}$ bağlamda kişilerarası duygu düzenleme modelinin bir psikoeğitim programıla deneysel bir müdahale ile ilk kez araştırılmış olması bu araştırmanın özgünlüğünü ortaya koymaktadır. Bu bilgiler doğrultusunda bu çalışmanın amacı; kişilerarası duygu düzenleme temelinde geliştirilen grup psikoeğitim programının beliren yetişkinlerin kişilerarası duygu düzenleme becerisine etkisinin deneysel olarak sınanmasıdır. Bu araştırma kapsamında aşağıdaki denencelere ve araştırma sorularına yanıt aranmıştır

\section{Araştırmanın Denenceleri}

- Deney grubundaki öğrencilerin son-test puanları ön-test puanlarından anlamlı düzeyde yüksektir.

- Kontrol grubundaki öğrencilerin son-test puanları ile ön-test puanları arasında anlamlı bir fark yoktur.

- Deney grubundaki öğrencilerin son-test puanları, kontrol grubundaki öğrencilerin son-test puanlarından anlamlı düzeyde yüksektir.

- Deney grubundaki öğrencilerin izleme testi puanları ile son-test puanları arasında anlamlı bir fark yoktur.

\section{Araştırma Soruları}

- Deney grubundaki öğrencilerin, grup psikoeğitim programı öncesinde kişilerarası duygu düzenleme becerilerine ilişkin görüşleri nelerdir?

- Deney grubundaki öğrencilerin, grup psikoeğitim programı sonrasında kişilerarası duygu düzenleme becerilerine ve psikoeğitim sürecine ilişkin görüşleri nelerdir?

\section{Yöntem}

\section{Araştırmanın Modeli}

$\mathrm{Bu}$ araştırma karma yöntem araştırma desenlerinden biri olan iç içe desende tasarlanmıştır. İç içe deneysel karma desende, öncelikli olarak deneysel programı test etmek ve bu kapsamda tasarlanan nicel yöntemi desteklemek amacıyla nitel yöntem desene dahil edilmektedir (Creswell, Fetters, Plano Clark ve Morales, 2009). Deneysel desende tasarlanan nicel araştırma içinde nicel verileri desteklemek amacıyla nitel araştırma deseni eklenmiştir $\mathrm{Bu}$ araştırmada kişilerarası duygu düzenleme yaklaşımına dayalı geliştirilen grup psikoeğitim programının etkililiğini incelemek için nicel olarak tasarlanan öntest, son-test, izleme testli yarı deneysel desenin içerisine deney grubu için sontest ölçümünde nitel veri toplama yöntemi gömülmüş̧ür. Deney grubuna grup psikoeğitim programı uygulanmıştır. Kontrol grubuna da herhangi bir işlem yapılmamıştır. Araştırmada deneysel işlem öncesinde ve deneysel işlemin bitiminde nicel ve nitel veri toplama yöntemleri deney grubuna aynı anda uygulanırken, kontrol grubuna sadece nicel veri toplama yöntemler uygulanmıştır. Ek olarak izleme testinde ise, deney grubunda nicel veri toplama yöntemi kullanılmıştır. Nicel veri toplama yöntemleri kapsamında ön test-son test ve izleme testi arasında anlamlı bir farklılık olup olmadığı kişilerarası duygu düzenleme ölçeği kullanılarak incelenmiştir (Bkz. Tablo 1). Nitel veri toplama yöntemleri kapsamında ise toplanan veriler son test uygulaması sonrasında deney grubundaki üyelerden grup değerlendirme formu aracılığıyla toplanmıştır.

Tablo 1

Araştırma Deseni

\begin{tabular}{|c|c|c|c|c|c|}
\hline & $\begin{array}{l}\text { Ön- } \\
\text { Test }\end{array}$ & Deneysel İşlem & $\begin{array}{l}\text { Son- } \\
\text { Test }\end{array}$ & Nitel Değerlendirme & $\begin{array}{l}\text { İzleme } \\
\text { Ölçümü }\end{array}$ \\
\hline Deney & $\mathrm{O} 1_{D}$ & $\begin{array}{c}\text { Kişilerarası Duygu Düzenleme } \\
\text { Programı }\end{array}$ & $\mathrm{O} 22_{\mathrm{D}}$ & $\begin{array}{l}\text { Grup Değerlendirme } \\
\text { Formu }\end{array}$ & $\mathrm{O} 3_{\mathrm{D}}$ \\
\hline Kontrol & Ö $1_{\mathrm{K}}$ & - & $\mathrm{O} 2_{\mathrm{K}}$ & - & $\mathrm{O} 3_{\mathrm{K}}$ \\
\hline
\end{tabular}

\section{Çalışma Grubu}

Araştırmanın katılımcıları, 2016-2017 Eğitim-Öğretim yılında bir Devlet Üniversitesinin Eğitim Fakültesinin üç farklı bölümü lisans programı birinci sınıfina devam eden 200 öğrenciden oluşan katılımcı havuzundan seçilmiştir. Katılımcılar seçilirken; geçmişte ya da şu anda psikiyatrik tedavi alan ve yakın zamanda ağır travmatik yaşantı geçiren öğrenciler ve Kısa Semptom Envanteri'den (KSE) 4 puan üzerinden değerlendirilen alt boyut puanları 2'den yüksek olan öğrenciler alınmamış, 
ardından Kişilerarası Duygu Düzenleme Ölçeği'den (KDDÖ) grup ortalamasının altında puan alan 40 öğrenci aday olarak belirlenmiştir. $\mathrm{Bu} 40$ öğrenciye psikoeğitim programına katılım için görüşme davet mesajı gönderilmiş; oturumlara katılabileceğini belirten 11 öğrenci ile bireysel görüşme yapılarak deney grubuna atamaları yapılmıştır. Ancak 1 üye oturumlar başlamadan katılmayacağını ifade etmiş gruptan çıkarılmıştır. Başka bir üye ise birinci oturuma katılmış ancak daha sonraki hiçbir oturuma katılmamıştır. Kontrol grubu ise kalan 29 üyeden rastgele atanan 10 kişi olarak belirlenmiştir. Daha sonra deney grubundaki bir kişinin azalması nedeniyle kontrol grubundan da rastgele çıkarılan 1 öğrenci ile kontrol grubu da 9 kişiye düşürülmüştür. Bu sebeple çalışma grubu 9'u deney 9'u kontrol olmak üzere $n=18$ kişiden oluşmaktadır. Bununla birlikte deney ve kontrol gruplarının kişilerarası duygu düzenleme ölçeğinden aldıkları ön test puanları arasında anlamlı farklılığın olup olmadığı Mann Whitney-U analizi ile incelenmiş analiz sonucunda deney ve kontrol gruplarının Pozitif Duygulanımı Artırma ( $U=32.00 ; p>.05)$, Teskin Edilme ( $U=40.00 ; p>.05)$, Sosyal Model Alma ( $U=34.00 ; p>.05)$ ve Perspektif Alma (U=32.00; $\mathrm{p}>.05)$ ön-test puan ortalamaları arasında anlamlı bir farklılık olmadığ görülmüş̧ür. Ayrıca deneysel çalışmaya başlamadan önce bilimsel araştırma etiği açısından sakınca olmadığı ve araştırmanın uygulanabilirliği konusunda Muğla Sitkı Koçman Üniversitesi, İnsan Araştırmaları Etik Kurulundan "Etik Kurul Raporu" (Karar tarihi: 04.01.2017; Protokol No: 8-2017) alınmıştır.

\section{Psikoeğitim Grup Oturumları ve İçeriği}

Kişilerarası duygu düzenleme kavramı oldukça yeni ve dünyada da son zamanlarda çalışılan ve araştırılan bir konu olduğu için ilgili kuramsal çerçeve sınırlıdır. Bu kapsamda konu ile ilgili kaynaklar: Zaki ve Williams (2013) "Kişilerarası Duygu Düzenleme (Interpersonal Emotion Regulation)" adlı kavramı ilk ortaya koydukları makale ve Hofmann, Carpenter ve Curtiss (2016) "Kişileraras1 Duygu Düzenleme Ölçeği (Interpersonal Emotion Regulation Questionnaire" makalesidir. Zaki ve Williams kişilerarası duygu düzenleme kavramını açıklarken ve tanıtırken; Hofmann, Carpenter ve Curtiss (2016) bu kavram için ölçek geliştirmişlerdir.

Program hazırlanırken ölçeğin alt boyutlarını oluşturan dört kişiler arası duygu düzenleme stratejisi temel alınarak sekiz oturum planlanmıştır. Program geliştirilme aşamasında da PDR alanında bir öğretim üyesi ve PDR alanında doktora yapan iki psikolojik danışman tarafından katkı sağlanmıştır. Program hazırlık ve geliştirilme kısmında etkinlik yazım, seçim, süre kontrolü konusunda ortak karar verilmiştir. Oturumlarda ele alınacak örnek durumlar ve örnek cümleler birlikte değerlendirilmiş, etkinliklerin içeriğinin amaca uygun olup olmadığı birlikte tartışılarak ele alınmıştır. Programın uygulanması süreci de yine PDR alanında bir öğretim üyesinin süpervizyonunda gerçekleştirilmiştir. $\mathrm{Bu}$ süpervizyonun gerçekleştirilmesi amacıyla oturumlar üyelerin de onayı alınarak kayıt altına alınmıştır. Program toplamda dört temel stratejiye yönelik sekiz oturumda gerçekleştirilmiştir. $\mathrm{Bu}$ oturumlara ait detaylar ise aşağıda açıklanmıştır:

Birinci oturum: Bu oturumun amacı üyelerin tanışması, kuralların ve işleyişin belirlenmesi, duygularla ilgili bilgi verilmesidir. Isınma oyunu ve tanışmanın ardından, psikoeğitim programının temel mantığ ve grup kuralları açıklanmıştır. Ardından duygular ve duyguların insan yaşamındaki yeri, kişilerarası duygu düzenleme beceri eğitimi grup uygulamasının amaçları, kuramsal temeli hakkında bilgi verilerek örneklerle açıklanmıştır. Üyelerin kişisel amaçlarını belirlemeleri sağlanarak özetleme ile oturum sonlandırılmış̧ır.

Íkinci oturum: $\mathrm{Bu}$ oturumun amac1 duyguların tanınmas1, ifade edilebilmesi ve bedensel yansımalarının farkında olunmasıdır. Isınma ve bir önceki oturumun özetlenerek başlanmış, ardından duygular hakkında konuşulmuş ve bilinen duyguların listesi oluşturulmuş ve oluşturulan liste üzerinden "Duygusal Ayna" etkinliği gerçekleştirilmiştir. Daha sonra yaşanılan durumlarda hissedilen duyguların belirlenebilmesi ve duyguların bedensel yansımalarının farkına varılması amacıyla "Duygum ne?" ile "Bedensel Farkındalık" etkinliği gerçekleştirilmiş ve oturum özetlenerek sonlandırılmıştır.

Üçüncü oturum: Bu oturumun amacı diğer insanları anlamak, anladığını ifade etmek ve bunu yapma motivasyonunu keşfetmektir. Isınma etkinliği ve bir önceki oturum özetlenerek başlanmış, ardından "Empati nedir ne anlıyoruz?", "Neden kişilerarası ilişkilerde bu kadar önemlidir?" soruları ile grup paylaşımları yapılmıştır. Daha sonra beş farklı duyguyu içeren örnek senaryo cümleleri okunmuş ve grup üyelerinden "...hissediyorsun ไhissetmişsin çünkü ........" şeklinde empatik cümle kalıbıyla cümleleri tamamlama çalışması yapılmıştır. Ardından ikili gruplar halinde duygu paylaşımı ile 
empatik tepki çalışması pekiştirilmiştir. Oturum özetlenerek, hafta içi empatik tepki verme çalışmaları ve kaydetme ev ödevi verilerek oturum sonlandırılmıştır.

Dördüncü oturum: Bu oturumun amacı rahatlama ve şefkat için diğer insanlarla temasa geçmenin anlamının öğretilmesidir. Isınma ve özetlemenin ardından ev ödevi hakkında konuşulmuştur. Daha sonra üzüntü, depresyon vb. olumsuz duygu durumunda, rahatlama ve şefkat için diğer insanları doğru zamanda aramayı ve duygu düzenleme stratejisi olarak "Teskin edilme stratejisini” öğretmek amacıyla yakın zamanda yaşadıkları, bir olay ya da durumu düşünmeleri ve ilgili olayda onları sakinleştiren cümle ve yaklaşım konusunda paylaşımlar yapmaları istenmiştir. Sonraki çalışmada ise teskin eden kişi olmanın duygusal yansımalarını fark ettirme ve günlük hayatta kullanım alışkanlığını kazandırmak için yakın zamanda yaşadıkları olayın arkadaşlarının başına gelmesi durumunda onu rahatlatacak ve teskin edecek yaklaşım ve cümleler üzerinde durulmuştur. Son olarak teskin edilme süreci aşamalandırılarak doğru zamanlamanın önemi örneklerle açıklanmıştır. Özetleme ve hafta içi üzücü, mutsuz edici bir olayda iki arkadaşı arama gibi tepkilerini not alarak karşılaştırma ev ödevi verilerek oturum sonlandırılmıştır.

Beşinci oturum: $\mathrm{Bu}$ oturumun amacı benzer olumsuz duygu durumu yaşayan grup üyelerinin bu durumlarla nasıl baş ettiklerini paylaşmaları ve sosyal model alma becerisinin kazandırılmasıdır. Isınma ve özetlemenin ardından ev ödevi hakkında konuşulmuştur. Daha sonra benzer olumsuz duygu durumunu yaşayan diğer insanların yaşanan durumlarla nasıl baş ettiklerini anlamak ve duygu düzenleme stratejisi olarak "Sosyal model alma stratejisini" ele almak amaciyla dört farklı senaryoda "sevgiliden ayrılma/kavuşamama, ev/yurt arkadaşlarıyla problem yaşama, okula uyum sorunları, aile ile ilgili problemlerde" yaşanılan duygular bu duyguların nasıl ve ne yoğunlukta yaşandığının belirlenmesi amacıyla etkinlik yapılmıştır. Daha sonra olumsuz duyguların düzenlenmesinde, benzer durumları yaşamış ve benzer duyguları hissetmiş kişilerin bu durumlarla nasıl baş ettiklerini bilmenin duygu düzenlemede nasıl kullanılabileceği ile ilgili paylaşımda bulunulmuş ve duygu düzenlemede sosyal model alma ile ilgili bilgi ve deneyimler paylaşılmıştır. Oturum özetlenerek ve üyelerden geri dönüt alınarak sonlandırılmıştır.

Altıncı oturum: $\mathrm{Bu}$ oturumun amac1 üyelere kişilerarası etkileşimlerde perspektif alma becerisini kazandırmaktır. Isınma ve bir önceki oturum özetlenmiş, ardından yaşanılan olumsuz durum veya olayın, daha kötü olabileceği veya başkalarının daha kötü biçimde yaşamış/yaşıyor olabileceği farkındalığını kazandırmak amacıyla duygu düzenleme stratejisi olarak "Bakış açısı alma stratejisinin" olumsuz duyguları düzenlemede kullanılması ile ilgili kuramsal bilgiler aktarılmıştır. Daha sonra drama tekniği ile bu stratejinin kullanılabileceği durumlarla ilgili farkındalık kazandırılmış ve günlük hayatta kullanımına dair örnekler verilmiştir. Oturumun özetlenerek ve üyelerden geri dönüt alınarak sonlandırılmıştır

Yedinci oturum: $\mathrm{Bu}$ oturumun amacı Mutluluğu ve neşeyi arttırmak için diğer insanlarla birlikte olmanın farkındalığını kazandırmaktır. Isınma etkinliği yapılarak ve bir önceki oturum özetlenerek başlanmıştır. Ardından mutluluk ve neşe gibi pozitif duyguları paylaşmanın olumlu etkisinin farkına varılması ve olumlu kişilerarası duygu düzenleme stratejisi olarak "Pozitif duygulanımı arttırma" stratejisini öğretmek amacıyla "Mutlu Haber" isimli etkinlik uygulanmıştır. Daha sonra mutluluk duygusunun paylaşıldıkça çoğalan bir duygu olduğu anlatılmış ve pozitif duygulanımı arttırmanın önemi konusunda grup paylaşımları alınmıştır. Özetleme ve "mutluluk listesi”" adı verilen mutlu eden kişiler ve eylemler ev ödevi ile oturum sonlandırılmıştır.

Sekizinci oturum: $\mathrm{Bu}$ oturumun amac1 genel değerlendirme ve bireysel kazanımların değerlendirilmesidir. Isınma ve özetlemenin ardından ev ödevi hakkında konuşulmuştur. Daha sonra geçmiş oturumlar özetlenmiş ardından tüm grup üyelerinin oturumlarda edindikleri kişilerarası duygu düzenleme becerileri ve grup yaşantısından elde ettikleri kazanımlar paylaşılmıştır. Ardından üyelerin başlangıçtaki kişisel amaçlarına ne ölçüde ulaştıkları belirlenmiştir. Lider ve üyelerce grup sürecinin genel değerlendirmesi yapılmış daha sonra son test uygulaması ve grup değerlendirme formu doldurulması ile süreç sonlandırılmıştır.

\section{Veri Toplama Araçları}

\section{Kişisel Bilgi Formu}

Kişisel bilgi formu birinci araştırmacı tarafından hazırlanmış olup; araştırmaya katılan bireyin cinsiyet, yaş, bölüm, telefon numarası ve e-posta bilgilerini içermektedir. Ayrıca kişisel bilgi formunda, katılımcıların grup psikoeğitim programından faydalanmasını zorlaştırabilecek ve araştırmanın 
sonuçlarını etkileyebilecek geçmişte ya da şu anda psikiyatrik tedavi alma ve yakın zamanda ağır travmatik yaşantı geçirme durumuna ilişkin evet ve hayır şeklinde cevaplanacak iki kapalı uçlu soru sorulmuştur (Yalom, 1995).

\section{Kişilerarası Duygu Düzenleme Ölçeği (KDDÖ)}

Kişilerarası Duygu Düzenleme Ölçeği Hofmann, Carpenter ve Curtiss (2016) tarafindan geliştirilmiştir. Beş dereceli Likert tipi ( $1=$ bana hiç uygun değil, $2=$ biraz uygun, $3=$ =uygun, $4=$ oldukça uygun, $5=$ tamamen uygun) olarak değerlendirilen toplam 20 maddeden oluşan ölçek, her biri 5 maddeden oluşan dört alt boyuttan oluşmaktadır. Ölçekteki her alt boyuttan en fazla puan 25 puan alınabilmekte ve puanlar yükseldikçe o duygu düzenleme stratejisinin daha çok kullanıldığı anlamına gelmektedir. Ölçeğin alt boyutları Pozitif Duygulanımı Artırma, Perspektif Alma, Teskin Edilme ve Sosyal Model Alma olarak isimlendirilmiştir.

Ölçeğin Türkçeye uyarlaması, ölçeği geliştiren araştırmacılardan izin alınarak Sarıcaoğlu (2020) tarafından yapılmışıır. Doğrulayıcı faktör analizi 431 üniversite öğrencisinden elde edilen veriler üzerinde yapılmış ve özgün ölçekteki dört faktörlü yapı doğrulanmıştır. Elde edilen uyum indekslerine $\left(\chi=387.67 \mathrm{sd}=164, \chi^{2} / \mathrm{sd}=2.30 \mathrm{p}<.001 ; \mathrm{RMSEA}=06 ; \mathrm{GFI}=.91 ; \mathrm{CFI}=.98 ; \mathrm{SRMR}=.04 ; \mathrm{NFI}=.96\right.$; NNFI=.97) göre modelin uyumlu olduğu ve modelin yapısını doğruladığı söylenebilir. Ölçeğin Cronbach alfa iç tutarlık katsayıları: Ölçeğin toplamı için .91, Pozitif Duygulanımı Artırma alt ölçeği için .84, Perspektif Alma .79, Teskin Edilme .86 ve Sosyal Model Alma için .83 olarak hesaplanmıştır. Ölçeğin faktör yükleri incelendiğinde: Pozitif duygulanımı arttırma alt ölçeği için .68 ile .76 arasında, Perspektif Alma alt ölçeği için .56 ile .75 arasında, Teskin Edilme alt ölçeği için .62 ile .81 arasında, Sosyal Model Alma alt ölçeği için .54 ile .78 arasında değişmektedir.

Değişkenlere ilişkin ifadelerin birbirleriyle ve oluşturdukları faktör ile ilişkisini ortaya koyan yakınsak geçerlik için bileşik güvenirlik (CR-composite reliability) değerleri incelenmiştir. Buna bağlı olarak: Pozitif Duygulanımı Artırma alt ölçeği için CR değeri .84; Perspektif Alma alt ölçeği için CR değeri .79; Teskin Edilme alt ölçeği için CR değeri .86 ve Sosyal Model Alma alt ölçeği için CR değeri .83 olarak elde edilmiştir.

\section{Kisa Semptom Envanteri (KSE)}

Çeşitli psikolojik belirtileri belirlemek için kullanılan KSE, 53 maddeden oluşan ve Likert tipi bir kendini değerlendirme ölçeğidir. Derogatis (1992) tarafından kısaltılan KSE'nin Türkçeye uyarlaması, geçerlik ve güvenirlik çalışmaları Şahin ve Durak (1994) tarafından yapılmışırı. Uyarlama çalışması kapsamında yapılan doğrulayıcı faktör analizi sonucunda ölçeğin beş faktörlü (anksiyete, depresyon, olumsuz benlik, somatizasyon ve hostilite) bir yapı sergilediği görülmüştür. Ölçüt bağıntılı geçerlik çalışması kapsamında da sosyal karşılaştırma ölçeğiyle .14 ve .34, UCLA yalnızlık ölçeğiyle .13 ve .36 Offer yalnızlık ölçeğiyle .34 ve .57 ve Beck depresyon envanteriyle .34 ve .70 arasında değişen korelasyonlar gösterdiği belirlenmiştir. Güvenirlik çalışması kapsamında elde edilen Cronbach alfa iç tutarlık katsayıları .96 ve .95 , alt ölçekler için elde edilen katsayılar ise .55 ile .86 arasında değişmektedir. Ölçeklerden alınan toplam puanların yüksekliği, bireyin semptomlarının sıklığını gösterir. Rahatsızlık ciddiyeti indeksi; alt ölçeklerin toplamının 53'e bölünmesi yoluyla elde edilmektedir. Belirti toplam indeksi ise 0 olarak işaretlenen maddeler dışındaki tüm maddelerin 1 kabul edilmesi ile elde edilen toplam puandır. Bu çalışmada bu ölçek, deney ve kontrol gruplarında yer alacak öğrencilerin belirlenmesinde kullanılmıştır. Alt boyuttan alınan puanlar, alt boyuttaki madde sayısına bölünerek 2 ve üzerinde çıkan sonuçlar araştırmadan çıkarılmıştır.

\section{Grup Değerlendirme Formu}

Deney grubuna 8 oturum sonunda kendilerini ve psikoeğitim grubunu değerlendirebilecekleri 9 başlıkta karşılaştırmalı durumlar yöneltilmiştir. Bu sorular: "Grup Öncesinde Sosyal İlişkilerim- Grup Sonrasında Sosyal İlişkilerim", "Grup öncesinde duygu düzenleme becerim- Grup sonrasında duygu düzenleme becerim", "Grup öncesinde arkadaşlarıma göre ben- Grup sonrasında arkadaşlarıma göre ben", "Grup sürecince kendimde meydana gelen değişiklik", "Kişilerarası ilişkilerimde değişen şey" ve son olarak "Benim için en öğretici oturum/lar" şeklindedir.

\section{Verilerin Analizi}

Araştırmanın nicel yöntemle toplanan verilerin analizinde öntest, sontest ve izleme testi ölçümlerinden elde edilen puanların gruplar arası varyansların homojenliği ve normal dağılım varsayımlarını karşılamadığı için parametrik yerine Non-parametrik testler kullanılmıştır. Non-parametrik testlerden 
Wilcoxon Sıralı İşaretler Testi ve Mann Whitney U Testi kullanılmıştır. Nitel kısmı için ise üyelerin görüşlerini yansıtan nitel veriler içerik analizi yöntemi ile analiz edilmiştir. İçerik analizinde temel amaç, toplanan verileri açıklayabilecek kavramalara ve ilişkilere ulaşmaktır. İçerik analizinde temelde yapılan işlem, birbirine benzeyen verileri belirli kavramlar ve temalar çerçevesinde bir araya getirmek ve bunları okuyucunun anlayabileceği bir biçimde organize ederek yorumlamaktır (Yıldırım ve Şimşek, 2013)

\section{Bulgular}

\section{Nicel Bulgular}

Deney ve kontrol grubunda yer alan öğrencilerin, Kişilerarası Duygu Düzenleme Ölçeğinin (KDDÖ) alt boyutlarından ön-test, son-test ve izleme testinde aldıkları puanlara ilişkin aritmetik ortalama, standart sapma puanları Tablo 2'de gösterilmiştir.

Tablo 2

Deney ve Kontrol Grubu, Ön-test, Son-test ve İzleme Testi İ̧sel Kişilerarası Duygu Düzenleme Alt Boyutları Puan Ortalamaları ve Standart Sapmalart

\begin{tabular}{|c|c|c|c|c|c|c|}
\hline \multirow{2}{*}{ Pozitif Duygulanımı Artırma } & \multicolumn{3}{|c|}{ Deney Grubu } & \multicolumn{3}{|c|}{ Kontrol Grubu } \\
\hline & $N$ & $\bar{X}$ & Ss & $N$ & $\bar{X}$ & Ss \\
\hline Ön-Test & 9 & 18.67 & 2.74 & 9 & 18.00 & 2.29 \\
\hline Son-Test & 9 & 21.68 & 3.16 & 9 & 18.00 & 3.71 \\
\hline İzleme & 9 & 20.56 & 2.96 & 9 & 17.22 & 3.56 \\
\hline \multirow{2}{*}{ Teskin Edilme } & \multicolumn{3}{|c|}{ Deney Grubu } & \multicolumn{3}{|c|}{ Kontrol Grubu } \\
\hline & $N$ & $\bar{X}$ & $S s$ & $N$ & $\bar{X}$ & Ss \\
\hline Ön-Test & 9 & 12.00 & 2.00 & 9 & 11.89 & 3.59 \\
\hline Son-Test & 9 & 18.22 & 4.18 & 9 & 11.44 & 4.00 \\
\hline İzleme & 9 & 18.00 & 4.64 & 9 & 10.00 & 4.80 \\
\hline \multirow{2}{*}{ Sosyal Model Alma } & \multicolumn{3}{|c|}{ Deney Grubu } & \multicolumn{3}{|c|}{ Kontrol Grubu } \\
\hline & $N$ & $\overline{\bar{X}}$ & Ss & $N$ & $\overline{\bar{X}}$ & Ss \\
\hline Ön-Test & 9 & 12.33 & 2.92 & 9 & 13.11 & 3.55 \\
\hline Son-Test & 9 & 19.22 & 2.68 & 9 & 12.44 & 4.03 \\
\hline İzleme & 9 & 19.22 & 3.87 & 9 & 10.78 & 4.06 \\
\hline \multirow{2}{*}{ Perspektif Alma } & \multicolumn{3}{|c|}{ Deney Grubu } & \multicolumn{3}{|c|}{ Kontrol Grubu } \\
\hline & $N$ & $\overline{\bar{X}}$ & $S s$ & $N$ & $\overline{\bar{X}}$ & Ss \\
\hline Ön-Test & 9 & 10.78 & 3.31 & 9 & 12.78 & 3.77 \\
\hline Son-Test & 9 & 17.00 & 1.50 & 9 & 11.89 & 2.57 \\
\hline İzleme & 9 & 15.67 & 3.97 & 9 & 11.56 & 3.32 \\
\hline
\end{tabular}

Tablo 2'de deney ve kontrol gruplarının pozitif duygulanımı arttırma, teskin edilme, sosyal model alma ve perspektif alma alt boyutlarında ön test, son test ve izleme testi puanları verilmiştir. Buna göre ölçümler ve gruplar arasında anlamlı farklılığın olup olmadığını incelemek için aşağıdaki denenceler test edilmiştir.

\section{Denence: Deney Grubundaki Öğrencilerin Son-Test Puanları Ön-Test Puanlarından Anlamlı Düzeyde Yüksektir Denencesine İlişkin Bulgular}

Araştırmanın birinci denencesine ilişkin sonuçlar, Tablo 3'te gösterilmiştir. 
Tablo 3

Deney Grubunun Ön-Test ve Son-Test Puanlarının Karşılaştırılmasına İlişkin Wilcoxon Testi Sonuçları

\begin{tabular}{|c|c|c|c|c|c|c|}
\hline & Siralar & $N$ & S.O. & S.T. & $z$ & $P$ \\
\hline \multirow{4}{*}{$\begin{array}{l}\text { Pozitif Duygulanımı } \\
\text { Artırma }\end{array}$} & Negatif Siralar & 2 & 1.50 & 3.00 & \multirow{4}{*}{-2.32} & \multirow{4}{*}{$.02 *$} \\
\hline & Pozitif Siralar & 7 & 6.00 & 42.00 & & \\
\hline & Eşit & 0 & & & & \\
\hline & Toplam & 9 & & & & \\
\hline \multirow{4}{*}{ Teskin Edilme } & Negatif Siralar & 0 & .00 & .00 & \multirow{4}{*}{-2.54} & \multirow{4}{*}{$.01 *$} \\
\hline & Pozitif Siralar & 8 & 4.50 & 36.00 & & \\
\hline & Eşit & 1 & & & & \\
\hline & Toplam & 9 & & & & \\
\hline \multirow{4}{*}{ Sosyal Model Alma } & Negatif Siralar & 0 & .00 & .00 & \multirow{4}{*}{-2.67} & \multirow{4}{*}{$.01 *$} \\
\hline & Pozitif Siralar & 9 & 5.00 & 45.00 & & \\
\hline & Eşit & 0 & & & & \\
\hline & Toplam & 9 & & & & \\
\hline \multirow{4}{*}{ Perspektif Alma } & Negatif Siralar & 0 & .00 & .00 & \multirow{4}{*}{-2.67} & \multirow{4}{*}{$.01 *$} \\
\hline & Pozitif Suralar & 9 & 5.00 & 45.00 & & \\
\hline & Eșit & 0 & & & & \\
\hline & Toplam & 9 & & & & \\
\hline
\end{tabular}

$* \mathrm{p}<.05$

Tablo 3'de görüldügü gibi, Wilcoxon testi sonucunda deney grubunun Pozitif Duygulanımı Artırma $(\mathrm{z}=-2.32 ; \mathrm{p}<.05)$, Teskin Edilme $(\mathrm{z}=-2.54 ; \mathrm{p}<.05)$, Sosyal Model Alma $(\mathrm{z}=-2.67 ; \mathrm{p}<.05)$ ve Perspektif Alma $(\mathrm{z}=-2.67 ; \mathrm{p}<.05)$ ön-test puanları ile son-test puanları arasında anlamlı düzeyde fark olduğu ve bu farkın sontest puanları lehine olduğu görülmektedir. Bu sonuç ile yapılan deneysel işlem ile deney grubunda yer alan üyelerin kişilerarası duygu düzenleme düzeyleri üzerinde artış sağlandığı ortaya konmuştur. Bu sonuç da araştırmanın birinci denencesinin doğrulandığını göstermektedir. Bu artışa ilişkin etki büyüklüklerinin .13 ile .15 arasında değiştiği ve bu etkinin küçük (small) düzeyde olduğu görülmektedir (Cohen, 2013).

II. Denence: Kontrol Grubundaki Öğrencilerin Son-Test Puanları İle Ön-Test Puanları Arasında Anlamlı Bir Fark Yoktur Denencesine İlișkin Bulgular

Araştırmanın ikinci denencesine ilişkin bulgular, Tablo 4'te gösterilmiştir.

Tablo 4

Kontrol Grubunun Ön-Test ve Son-Test Puanlarının Karşılaştırılmasına İlişkin Wilcoxon Testi Sonuçları

\begin{tabular}{|c|c|c|c|c|c|c|}
\hline & Siralar & $N$ & S.O. & S.T. & $z$ & $P$ \\
\hline \multirow{4}{*}{$\begin{array}{l}\text { Pozitif Duygulanımı } \\
\text { Artırma }\end{array}$} & Negatif Siralar & 4 & 4.50 & 18.00 & \multirow{4}{*}{.00} & \multirow{4}{*}{1.00} \\
\hline & Pozitif Sıralar & 4 & 4.50 & 18.00 & & \\
\hline & Eşit & 1 & & & & \\
\hline & Toplam & 9 & & & & \\
\hline \multirow{4}{*}{ Teskin Edilme } & Negatif Siralar & 4 & 3.75 & 15.00 & \multirow{4}{*}{-.17} & \multirow{4}{*}{.87} \\
\hline & Pozitif Siralar & 3 & 4.33 & 13.00 & & \\
\hline & Eşit & 2 & & & & \\
\hline & Toplam & 9 & & & & \\
\hline \multirow{4}{*}{ Sosyal Model Alma } & Negatif Siralar & 4 & 4.50 & 18.00 & \multirow{4}{*}{-.68} & \multirow{4}{*}{.50} \\
\hline & Pozitif Siralar & 3 & 3.33 & 10.00 & & \\
\hline & Eşit & 2 & & & & \\
\hline & Toplam & 9 & & & & \\
\hline \multirow{4}{*}{ Perspektif Alma } & Negatif Siralar & 5 & 3.70 & 18.50 & \multirow{4}{*}{-.76} & \multirow{4}{*}{.45} \\
\hline & Pozitif Siralar & 2 & 4.75 & 9.52 & & \\
\hline & Eşit & 2 & & & & \\
\hline & Toplam & 9 & & & & \\
\hline
\end{tabular}

Tablo 4'te görüldüğü gibi, kontrol grubu ön-test ve son-test puanlarının karşılaştırılmasına ilişkin yapılan analiz sonucunda Pozitif Duygulanımı Artırma ( $z=.00 ; p>.05)$, Teskin Edilme ( $z=-.17 ; p>.05)$, 
Sosyal Model Alma (z=-.68; p>.05) ve Perspektif Alma ( $\mathrm{z}=-.76 ; \mathrm{p}>.05)$ alt boyutlarda puanlar arasında anlamlı bir farklılık olmadığı görülmüsstür. Dolayısıyla bu bulgu da deneysel işlem uygulanmayan kontrol grubunun puanlarında değişim olmadığını ortaya koymuş ve araştırmanın ikinci denencesi doğrulanmıştır.

III. Denence: Deney Grubundaki Öğrencilerin Son-Test Puanları, Kontrol Grubundaki Öğrencilerin Son-Test Puanlarından Anlamlı Düzeyde Yüksektir Denencesine İlişkin Bulgular

Araştırmanın üçüncü denencesine ilişkin sonuçlar, Tablo 5'te gösterilmiştir.

Tablo 5

Deney ve Kontrol Grubu Son-Test Puanlarının Karşılaştırılmasına Illişkin Mann Whitney-U Testi Sonuçları

\begin{tabular}{|c|c|c|c|c|c|c|c|}
\hline & Grup & $N$ & S.O. & S.T. & $\boldsymbol{U}$ & $z$ & $p$ \\
\hline \multirow{2}{*}{ Pozitif Duygulanımı Artırma } & Deney & 9 & 12.00 & 108.00 & \multirow{2}{*}{18.00} & \multirow{2}{*}{-2.00} & \multirow{2}{*}{$.03 *$} \\
\hline & Kontrol & 9 & 7.00 & 63.00 & & & \\
\hline \multirow{2}{*}{ Teskin Edilme } & Deney & 9 & 13.33 & 120.00 & \multirow{2}{*}{6.00} & \multirow{2}{*}{-3.05} & \multirow{2}{*}{$.00 *$} \\
\hline & Kontrol & 9 & 5.67 & 51.00 & & & \\
\hline \multirow{2}{*}{ Sosyal Model Alma } & Deney & 9 & 13.06 & 117.50 & \multirow{2}{*}{8.50} & \multirow{2}{*}{-2.84} & \multirow{2}{*}{$.00^{*}$} \\
\hline & Kontrol & 9 & 5.94 & 53.50 & & & \\
\hline \multirow{2}{*}{ Perspektif Alma } & Deney & 9 & 13.28 & 119.50 & \multirow{2}{*}{6.50} & \multirow{2}{*}{-3.03} & \multirow{2}{*}{$.00 *$} \\
\hline & Kontrol & 9 & 5.72 & 51.50 & & & \\
\hline
\end{tabular}

$* \mathrm{p}<.05$

Tablo 5'te görüldüğ ü gibi, deney ve kontrol grubunun son-test puanlarının karşılaştırılmasına ilişkin yapılan Mann Whitney-U analizi sonucunda deney ve kontrol gruplarının Pozitif Duygulanımı Artırma ( $U=18.00 ; p<.05)$, Teskin Edilme $(U=6.00 ; p<.05)$, Sosyal Model Alma $(U=8.50 ; p<.05)$ ve Perspektif Alma (U=6.50; $\mathrm{p}<.05)$ son-test puan ortalamaları arasında deney grubu lehine anlamlı bir farklılık olduğu görülmüştür. Elde edilen sonuca göre araştırmanın üçüncü denencesi doğrulanmıştır.

\section{Denence: Deney Grubundaki Öğrencilerin İzleme Testi Puanları İle Son-Test Puanları Arasında Anlamlı Bir Fark Yoktur Denencesine İlișkin Bulgular}

Araştırmanın dördüncü denencesine ilişkin sonuçlar, Tablo 6'da gösterilmiştir.

Tablo 6

Deney Grubunun İzleme Testi ve Son-Test Puanlarının Karşılaştırllmasına Illişkin Wilcoxon Testi Sonuçları

\begin{tabular}{|c|c|c|c|c|c|c|}
\hline & Siralar & $\bar{N}$ & S.O. & S.T. & $\bar{z}$ & $\bar{P}$ \\
\hline \multirow{4}{*}{$\begin{array}{l}\text { Pozitif Duygulanımı } \\
\text { Artırma }\end{array}$} & Negatif Siralar & 5 & 6.30 & 31.50 & \multirow{4}{*}{-1.07} & \multirow{4}{*}{.28} \\
\hline & Pozitif Siralar & 4 & 3.38 & 13.50 & & \\
\hline & Eşit & 0 & & & & \\
\hline & Toplam & 9 & & & & \\
\hline \multirow{4}{*}{ Teskin Edilme } & Negatif Siralar & 4 & 4.63 & 18.50 & \multirow{4}{*}{-.07} & \multirow{4}{*}{.94} \\
\hline & Pozitif Siralar & 4 & 4.38 & 17.50 & & \\
\hline & Eşit & 1 & & & & \\
\hline & Toplam & 9 & & & & \\
\hline \multirow{4}{*}{ Sosyal Model Alma } & Negatif Siralar & 4 & 5.13 & 20.50 & \multirow{4}{*}{-.24} & \multirow{4}{*}{.81} \\
\hline & Pozitif Siralar & 5 & 4.90 & 24.50 & & \\
\hline & Eşit & 0 & & & & \\
\hline & Toplam & 9 & & & & \\
\hline \multirow{4}{*}{ Perspektif Alma } & Negatif Siralar & 5 & 5.60 & 28.00 & \multirow{4}{*}{-.66} & \multirow{4}{*}{.51} \\
\hline & Pozitif Siralar & 4 & 4.25 & 17.00 & & \\
\hline & Eşit & 0 & & & & \\
\hline & Toplam & 9 & & & & \\
\hline
\end{tabular}

Deney grubu izleme testi ve son test puanlarının karşılaştırılmasına ilişkin yapılan analiz sonucunda Pozitif Duygulanımı Artırma ( $\mathrm{z}=-1.07 ; \mathrm{p}>.05)$, Teskin Edilme ( $\mathrm{z}=-.07 ; \mathrm{p}>.05)$, Sosyal Model Alma $(\mathrm{z}=-.24 ; \mathrm{p}>.05)$ ve Perspektif Alma $(\mathrm{z}=-.66 ; \mathrm{p}>.05)$ alt boyutlarda puanlar arasinda anlamlı bir farklılık olmadığ1 görülmüştür (Bkz. Tablo 6). Elde edilen bulgular, deney grubunda yer alan katılımciların 
deneysel işlem sonrası artan puanlarının kalıcı olduğunu göstermektedir. Bu sonuç da araştırmanın dördüncü denencesini doğrulamaktadır.

\section{Nitel Bulgular}

Çalışmanın nitel bulgularına ilişkin olarak grup değerlendirme formunda yer alan dokuz başlığa katılımcıların verdikleri cevapların içerikleri analiz edilmiş ve psikoeğitim öncesi ile psikoeğitim sonrasına dair kodlar, kategoriler ve temalar belirlenmiştir. Analiz sürecinde kodlar, kategoriler ve temalar belirlenirken PDR alanında bir öğretim üyesi ve PDR alanında doktora yapan iki psikolojik danışman tarafından birlikte oluşturulmuş ve nitel içerik analizi yapılmıştır. Araştırmanın nitel bulgularına ilişkin geçerliğine dair uzman incelemesi, ayrıntılı betimleme, ayrıntılı bilgi verme, özgün ve kalıcı sınıflandırma olmak üzere nitel geçerlilik yöntemleri sağlanmıştır. Nitel bulguların güvenirliğini sağlamak amacıyla; veri analizinde sonuçların başka bir araştırmacıyla teyit edilmesi, kuramsal çerçevenin, veri toplama şeklinin ve veri analizinin tanımlanması nitel güvenirlik yöntemleri kullanılmıştır (Yıldırım ve Şimşek, 2006). Güvenirlik çalışmaları için, eğitim bilimleri alanından iki öğretim üyesi ile bir araya gelinmiş ve elde edilen bulgular teyit edilmiş ve veri toplama ile analiz sürecinin yeterliliği onaylanmıştır. Bu doğrultuda aşağıdaki bulgu ve yorumlara ulaşılmıştır.

\section{Psikoeğitim Öncesi Kişilerarası Duygu Düzenlemeyle İlgili Görüşlerin Analizinden Ortaya Çıkan Kod, Kategori ve Temalar}

Tablo 7

Psikoeğitim Öncesine Illişkin Ortaya Çıkan Kod, Kategori ve Temalar

\begin{tabular}{|c|c|c|c|}
\hline Grup Üyelerinin İfadelerinden Örnekler & Kodlar & Kategoriler & Temalar \\
\hline $\begin{array}{l}\text { "Duygularım en çok baskın olan heyecanımı } \\
\text { ve sinirimi kontrol altına alamıyordum" }\end{array}$ & $\begin{array}{l}\text { Heyecanını ve } \\
\text { sinirini kontrol } \\
\text { edememe }\end{array}$ & $\begin{array}{l}\text { Duyguları Kontrol ve } \\
\text { Duygularla Baş } \\
\text { Edememe } \\
\end{array}$ & \multirow{3}{*}{$\begin{array}{l}\text { Kişilerarası } \\
\text { Duygu } \\
\text { Düzenleme } \\
\text { Becerisi }\end{array}$} \\
\hline $\begin{array}{l}\text { "Genelde tartıştığım insanla konuşmak yerine } \\
\text { müzik dinleyerek ya da o ortamdan } \\
\text { uzaklaşarak sakinleşmeye çalışıyordum" }\end{array}$ & $\begin{array}{l}\text { Uzaklaşarak } \\
\text { sakinleşme }\end{array}$ & $\begin{array}{c}\text { Duyguları Bastırma } \\
\text { veya Duygulardan } \\
\text { Kaçma }\end{array}$ & \\
\hline $\begin{array}{l}\text { "Olumsuz duygularım aşırıydl, bir anda } \\
\text { sinirlenen çok çabuk ters düşen biriydim ve } \\
\text { bunun az da olsa düzelmesini istiyordum." }\end{array}$ & $\begin{array}{l}\text { Duyguları ifade } \\
\text { ederken } \\
\text { zorlanma }\end{array}$ & $\begin{array}{l}\text { Duygu Düzenleme } \\
\text { Beceri Eksikliği }\end{array}$ & \\
\hline $\begin{array}{l}\text { "Insanları anlamakta ve duygularını } \\
\text { çözümlemede zorlandığım için bazı konularda } \\
\text { önyargıll yaklaşıyordum"” }\end{array}$ & $\begin{array}{l}\text { İnsanlara } \\
\text { önyarg1lı } \\
\text { yaklaşma }\end{array}$ & $\begin{array}{l}\text { İnsanları / Duyguları } \\
\text { Anlamada Güçlük }\end{array}$ & \multirow{2}{*}{$\begin{array}{l}\text { Empatik } \\
\text { Beceriler }\end{array}$} \\
\hline $\begin{array}{l}\text { "Çevremdekileri nasıl teselli edeceğimi tam } \\
\text { olarak bilmiyordum, onlara geri dönütü tam } \\
\text { olarak veremiyordum" }\end{array}$ & $\begin{array}{l}\text { Çevresindekileri } \\
\text { teselli edememe }\end{array}$ & $\begin{array}{l}\text { Etkili Tepkiler } \\
\text { Verememe }\end{array}$ & \\
\hline $\begin{array}{l}\text { "Karşımdaki kişiyle iletişim kurmaya } \\
\text { başlarken sıkıntı çekiyordum ve duygularımı } \\
\text { ifade ederken zorlanıyordum" }\end{array}$ & $\begin{array}{c}\text { İletişim } \\
\text { kurmada } \\
\text { zorlanma }\end{array}$ & $\begin{array}{l}\text { Kendini Doğru İfade } \\
\text { Edememe }\end{array}$ & \multirow{4}{*}{$\begin{array}{l}\text { Kişilerarası } \\
\text { İletişim Becerileri }\end{array}$} \\
\hline $\begin{array}{l}\text { "Karşımdaki insanlara daha mesafeli } \\
\text { yaklaşıyordum" }\end{array}$ & $\begin{array}{c}\text { İnsanlara } \\
\text { mesafeli } \\
\text { yaklaşma }\end{array}$ & Kişilerarası Mesafe & \\
\hline $\begin{array}{l}\text { "Stratejileri bilmediğim için karşımdaki } \\
\text { kişilerle iletişimde kullanamıyordum. Bu } \\
\text { yüzden birbirimizi anlamada eksiklikler } \\
\text { yaşlyorduk" }\end{array}$ & $\begin{array}{l}\text { Karşısındakini } \\
\text { anlamada sorun } \\
\text { yaşama }\end{array}$ & $\begin{array}{l}\text { İletişim Becerisi } \\
\text { Eksikliği }\end{array}$ & \\
\hline $\begin{array}{l}\text { "Karşımdaki kişiyle iletişim kurmaya } \\
\text { başlarken sıkıntı çekiyordum ve duygularımı } \\
\text { ifade ederken zorlanıyordum" }\end{array}$ & $\begin{array}{l}\text { Duyguları ifade } \\
\text { etmede } \\
\text { zorlanma }\end{array}$ & $\begin{array}{l}\text { İletişimi Başlatmada } \\
\text { Güçlük }\end{array}$ & \\
\hline $\begin{array}{l}\text { "Karşımdakini dinliyordum, kendimce } \\
\text { çözümler üretiyordum ama çok etkili } \\
\text { olamıyordum." }\end{array}$ & $\begin{array}{l}\text { Karşısındakine } \\
\text { yardımcı } \\
\text { olamama }\end{array}$ & Destek Olamama & \multirow{2}{*}{$\begin{array}{c}\text { Kişilerarası } \\
\text { İlişkilerde Destek }\end{array}$} \\
\hline $\begin{array}{l}\text { "Duygularımı kendim kontrol etmeye } \\
\text { çalışıyordum, başkalarıla olumsuz } \\
\text { duygularımı paylaşmaya sıcak bakmıyordum", }\end{array}$ & $\begin{array}{c}\text { Duyguları } \\
\text { paylaşmama }\end{array}$ & Destek Almama & \\
\hline
\end{tabular}


yönelik ifadelerde bulundukları ve bunların kişilerarası duygu düzenleme teması altında toplandığı görülmüştür. Üyelerin diğer cevaplarından ise insanları ve duyguları anlamada güçlük yaşama ve etkili tepkiler verememe kategorileri ortaya çıkmıştır. Bu kategorilerde empatinin bileşenleri olarak değerlendirildiğinden empati kuramama olarak temalaştırılmıştır. Benzer şekilde üyelerin; kendilerini doğru ifade edememe, kişilerarası mesafe, iletişim becerisi eksikliği ve iletişimi başlatmada güçlük cevapları üyelerin iletişim güçlügü yaşamaları ile ilişkilendirilip bu yönde temalaştırılmıştır. Grup üyelerinin destek olamama ve destek alamamaya ilişkin ifade örnekleri de kişilerarası ilişkilerde destek teması ile ilişkilendirilmiştir.

\section{Psikoeğitim Sonrası Kişilerarası Duygu Düzenlemeyle İlgili Görüşlerin Analizinden Ortaya Çıkan Kod, Kategori ve Temalar}

Tablo 8.

Psikoeğitim Sonrasina İlişkin Ortaya Çıkan Kod, Kategori ve Temalar

\begin{tabular}{|c|c|c|c|}
\hline Grup Üyelerinin İfadelerinden Örnekler & Kodlar & Kategoriler & Temalar \\
\hline $\begin{array}{l}\text { "Artık kendimi karşımdaki insanın yerine koyarak } \\
\text { onun haklı olduğu noktaları görüp çok daha kolay bir } \\
\text { şekilde sakinleşebilirim" }\end{array}$ & $\begin{array}{l}\text { Karşısındakini } \\
\text { anlama }\end{array}$ & $\begin{array}{l}\text { Karşıdaki Kişinin } \\
\text { Yerine Kendini } \\
\text { Koyma }\end{array}$ & \multirow{3}{*}{$\begin{array}{l}\text { Empatik } \\
\text { Beceriler }\end{array}$} \\
\hline $\begin{array}{l}\text { "Empati ve buna benzer stratejilerle kendimi onlartn } \\
\text { yerine koyarak daha iyi bir dinleyici haline geldim ve } \\
\text { önyargllarım azaldi"” }\end{array}$ & $\begin{array}{c}\text { İyi Bir Dinleyici } \\
\text { Olma }\end{array}$ & $\begin{array}{c}\text { Anlayarak } \\
\text { önyargııı azaltma }\end{array}$ & \\
\hline $\begin{array}{l}\text { "Artık çok fazla önyargılı değilim, karşımdakini } \\
\text { anlamadan, 'doğru zaman doğru kişi' ifadesini } \\
\text { düşünmeden kurmak yerine karşımdakinin } \\
\text { düşüncelerini anlayarak acaba onun da mı sıkıntıları } \\
\text { var, o şu an ne yaşıyor diye düş̧̈nmeye başladım” }\end{array}$ & $\begin{array}{l}\text { Karşısındakini } \\
\text { düşünme }\end{array}$ & $\begin{array}{l}\text { İnsanları / } \\
\text { Duyguları } \\
\text { Anlamada } \\
\text { Güçlenme }\end{array}$ & \\
\hline
\end{tabular}

\begin{tabular}{|c|c|c|c|}
\hline $\begin{array}{l}\text { "Doğru kişileri ve doğru zamanları bulduğumda } \\
\text { sorunlarımı veya mutluluklarımı paylaşarak } \\
\text { duygularımı düzenlemeyi ögrendim." }\end{array}$ & $\begin{array}{l}\text { Duyguları } \\
\text { paylaşma }\end{array}$ & $\begin{array}{l}\text { Duygu } \\
\text { Düzenleme } \\
\text { Stratejilerini } \\
\text { Kullanabilme }\end{array}$ & \multirow{3}{*}{$\begin{array}{l}\text { Kişilerarası } \\
\text { Duygu } \\
\text { Düzenleme } \\
\text { Becerisi }\end{array}$} \\
\hline $\begin{array}{l}\text { "Duygularımla nasıl başa çıkacă̆ımı ögrendim. Artık } \\
\text { kötü duygular yaşayınca ögrendiğim stratejiler } \\
\text { sayesinde bu duyguları kolaylıkla } \\
\text { düzenleyebiliyorum" }\end{array}$ & $\begin{array}{l}\text { Olumsuz } \\
\text { Duygularla baş } \\
\text { etme }\end{array}$ & $\begin{array}{l}\text { Duygu } \\
\text { Düzenlemede } \\
\text { Farkındalık }\end{array}$ & \\
\hline $\begin{array}{l}\text { "Özellikle teskin edilme ve sosyal model alma } \\
\text { stratejilerini hayatımda uygulayarak duygularımı } \\
\text { düzenleyebiliyorum” } \\
\text { "Doğru kişileri ve doğru zamanları bulduğumda } \\
\text { sorunlarımı veya mutluluklarımı paylaşarak } \\
\text { duygularımı düzenlemeyi ögrendim." }\end{array}$ & $\begin{array}{c}\text { Duyguların } \\
\text { düzenlenmesi }\end{array}$ & $\begin{array}{l}\text { Öğrenilen } \\
\text { Stratejileri } \\
\text { Uygulama }\end{array}$ & \\
\hline $\begin{array}{l}\text { "Yaşadığım sorunlarda yalnız olmadı̆̆ımı fark ettim. } \\
\text { Sorunlarımla boğuşmaktansa yakın çevremle } \\
\text { paylaşarak çözüme ulaşabileceğimi düşünüyorum." }\end{array}$ & $\begin{array}{c}\text { Sorunlarını } \\
\text { paylaşarak çözme }\end{array}$ & Destek Alma & \multirow{2}{*}{$\begin{array}{l}\text { Kişilerarası } \\
\text { İlişkilerde } \\
\text { Destek }\end{array}$} \\
\hline $\begin{array}{l}\text { "Arkadaşlarım daha anlayışlı olduğumu, duygularımı } \\
\text { iyi ifade ettiğimi söylediler ve bana duygularını } \\
\text { sıkıntılarını daha çok anlatma isteğinde bulundular" }\end{array}$ & Duygudaşlık & Destek Verme & \\
\hline $\begin{array}{l}\text { "Sosyal ilişkilerim biraz daha gelişti, duygu ve } \\
\text { düşüncelerimi rahat bir şekilde ifade edebilir hale } \\
\text { geldim" }\end{array}$ & $\begin{array}{l}\text { Etkileşimin } \\
\text { artması }\end{array}$ & $\begin{array}{l}\text { Kendini İfade } \\
\text { Etmede } \\
\text { Güçlenme } \\
\end{array}$ & \multirow{3}{*}{$\begin{array}{l}\text { Kişilerarası } \\
\text { İletişim } \\
\text { Becerileri }\end{array}$} \\
\hline $\begin{array}{l}\text { "Öğrendiğim stratejileri ilişkilerimde uygulayarak } \\
\text { çok daha güçlü ve karşıllılı olarak birbirimizi } \\
\text { anladığımız ilişkiler kurmaya başladım" }\end{array}$ & $\begin{array}{l}\text { Sosyal bağın } \\
\text { kuvvetlenmesi }\end{array}$ & $\begin{array}{l}\text { Kişilerarası } \\
\text { İlişkilerde } \\
\text { Güçlenme }\end{array}$ & \\
\hline $\begin{array}{l}\text { "Artık tanımadığım insanlarla da daha kolay bir } \\
\text { şekilde iletişime geçiyor, onlara duygularımı ve } \\
\text { düşüncelerimi ifade ediyorum" }\end{array}$ & $\begin{array}{l}\text { Kendini daha iyi } \\
\text { ifade etme }\end{array}$ & $\begin{array}{l}\text { İletişimi } \\
\text { Başlatmada } \\
\text { Güçlenme }\end{array}$ & \\
\hline
\end{tabular}

Psikoeğitim sonrası değerlendirmeler incelendiğinde grup üyelerinin ifadelerinin analizinden karşıdaki kişinin yerine kendini koyma, iyi bir dinleyici olma ve insanlarılduyguları anlamada güçlenme kategorileri ortaya çıkmıştır. Bu kategorilerde empati becerisinin öğeleri olarak değerlendirildiğinden Empatik Beceriler olarak temalaştırılmıştır. Benzer şekilde üyelerin ifadelerinden duygu düzenleme 
stratejilerini kullanabilme, duygu düzenlemede farkındalık ve öğrenilen stratejileri uygulama kategorileri üyelerin kişilerarası duygu düzenleme becerisi ile ilişkilendirilip bu yönde temalaştırılmıştır. Üyelerin grup sonrasında cevaplarından örnekler incelendiğinde; destek alma ve destek vermeye ilişkin kategorileri de kişilerarası ilişsilerde destek teması ile ilişkilendirilmiştir. Kendini ifade etmede güçlenme, kişilerarası ilişkilerde güçlenme ve iletişim başlatmada güçlenme kategorileri de kişilerarası iletişim becerilerinin unsurları olarak düşünüldüğünden Kişilerarası İletişim Becerileri olarak temalaştırılmıştır.

\section{Tartışma ve Sonuç}

$\mathrm{Bu}$ çalışmadan elde edilen bulgular üniversite öğrencilerine yönelik olarak hazırlanan kişilerarası duygu düzenleme yaklaşımı temelli geliştirilen grup psikoeğitim programının, öğrencilerin duygu düzenleme becerisini arttırdığını göstermektedir. Bu kapsamda Türkiye'de doğrudan bu konuda ile ilgili yapılan bir çalışma olmamasına rağmen, bu bulgular beliren yetişkinlerin duygu düzenleme stratejilerini ve iletişim becerilerini arttırmaya yönelik gerçekleştirilen deneysel çalışmaların bulguları ile tutarl11ık göstermektedir (Gülgez ve Gündüz, 2015; Şahin, 1997). Gülgez ve Gündüz (2015) gerçekleştirdikleri çalışmada, Diyalektik Davranış Terapisi (DDT) temelli duygu düzenleme programının, üniversite öğrencilerinin duygu düzenleme güçlüklerini azalttığını bildirmişlerdir. Benzer şekilde Şahin (1997) iletişim becerileri programına katılan üniversite öğrencilerinin iletişim becerilerinin programa katılmayan öğrencilere göre anlamlı bir şekilde arttığı bulgusu elde etmiştir. Bu çalışmanın sonuçları yukarıda belirtilen ilgili çalışmalar ile paralellik göstermektedir. Bu çalışmada hazırlanan psikoeğitim programının çekirdeğini oluşturan kişilerarası duygu düzenleme kavramı ve modeli Türkiye'de ölçek uyarlama çalışmaları dışında deneysel olarak sınanmamıştır. Kuzucu (2006), duygusal farkındalık ve duyguları ifade etmenin psikolojik ve öznel iyi oluş üzerindeki etkisi araştırdığı doktora tezinde; duyguları fark etmeye ve ifade etmeye yönelik geliştirdiği psikoeğitim programının öğrencilerin duygusal farkındalık düzeylerinin arttırmada etkili olduğu ancak, duyguları ifade etme eğilimlerinin psikolojik ve öznel iyi oluş düzeylerini arttırmada etkili olmadığ 1 sonucuna ulaşmıştır. Benzer şekilde bu çalışmadan elde edilen sonuçlara göre hazırlanan psikoeğitim programının beliren yetişkinlerin duygu düzenleme stratejilerini arttırma konusunda etkili olduğu görülmektedir.

Duygu düzenleme süreci, bireyin sosyalleşme sürecindeki erken dönem yaşantısından yetişkinlikteki iliş̧ki yapılarına kadar kritik öneme sahiptir (Higgins ve Pittman, 2008; Hofman 2014; Hofmann, Carpenter ve Curtiss, 2016; Shaver ve Mikulincer, 2007). Üniversite yaşamı sosyal ilişki ve deneyimlerin hızlı ve yoğun yaşandığı, gencin pek çok ilişki biçimi ile birlikte birçok duygusal zorluk ve zenginlik ile karşılaştığ 1 söylenebilir. Bu süreçte bireyler genellikle sosyal olarak izole edildiklerinde olumsuz etki yaşarken, sosyal bağ ve bağlılık bireyler üzerinde olumlu etkiler yaratmaktadır (Coan, 2011). Hofmann (2014) da sosyal ilişkilerin duyguları deneyimleme ve ifade etmedeki önemini vurgulamaktadır. Bu kapsamda duyguların ifadesi, duygu farkındalığı, duygu düzenleme süreçleri ve kişilerarası duygu düzenlemeye ilişkin farkındalık ve bilinçlendirmeye dayalı psikoeğitim programının beliren yetişkinlerin kişilerarası duygularını ifade etmelerine yardımcı olduğu görülmektedir.

$\mathrm{Bu}$ çalışmanın nitel kısmını içeren psikoeğitim sonrası değerlendirme formundan elde edilen sonuçlara göre; psikoeğitim programının öğrencilerin empati becerisini geliştirmelerine yardımcı olduğu görülmektedir. Grup psikoeğitim programının perspektif kazandırmaya yönelik oturum ve etkinliklerin, üyelerin bu becerilerinin gelişmesine yardımcı olduğu görülmektedir. Alanyazında Zaki ve Williams (2013) da empati ile kişilerarası duygu düzenleme arasındaki ilişkide bireyin kişilerarası duygu düzenlemesi için empatinin öncül olduğunu ifade etmişlerdir. Buna ilişkin olarak grup psikoeğitim programının, üyelerin kişilerarası duygu düzenleme becerisini geliştirmeye katk1 sağladığını göstermektedir.

Sorunlarını paylaşarak çözme ve duygudaşlık kodları destek alma ve vermenin öğretildiği oturumların ve etkinliklerin hedeflenen becerinin kazandırdığını göstermektedir. Özellikle teskin edilme ve teskin etme oturum etkinliklerinin bu becerilerinin gelişmesine yardımcı olduğu görülmektedir. Bir diğer nitel bulguda yer alan Duygu Düzenlemede Farkındalık ve Öğrenilen Duygu Düzenleme Stratejilerini Kullanabilme kategorileri Kişilerarası Duygu Düzenleme Becerisi ile temalaştırılmış; tüm oturumların geneli itibariyle kişiler arası duygu düzenleme becerisini arttırdığını göstermektedir. Yine psikoeğitim programının üyelerin kişilerarası iletişim becerileri becerisini geliştirmelerine yardımcı olduğu 
görülmektedir. Bu kapsamda grup üyelerinin kişilerarası iletişimi başlatma, süreçte güçlenme ve kendini ifade etmedeki becerilerin artışı üyelerin ifadelerinden elde edilen etkileşimin artması, sosyal bağın kuvvetlenmesi ve kendini daha iyi ifade etme kodlarından anlaşılmaktadır. Literatürde de kişilerarası duygu düzenleme ile bağlantılı olarak, sosyal paylaşımın, bireylerin olumlu ve olumsuz duygu deneyimlerini başkalarıyla paylaşma isteği olarak ifade edildiği görülmektedir (Rimé, Finkenauer, Luminet, Zech ve Philippot, 1998).

Kişilerarası duygu düzenleme becerisine ilişkin araştırmanın nitel basamağında yapılan deney grubuna ait psikoeğitim sürecine ilişkin geri dönütlerden elde edilen bulgular incelendiğinde beliren yetişkinlerin kişilerarası duygu düzenleme becerilerinde gelişim olduğu sonucuna ulaşılmıştır. Bununla birlikte deney grubunun gerek empatik becerileri gerekse kişilerarası iletişim becerilerinin gelişimi de programın hem nicel hem nitel çıktıları arasındadır. Araştırmanın modeli doğrultusunda yapılan içerik analizinden elde edilen bu nitel bulgular nicel sonuçları desteklemiş ve zenginleştirmiştir. Sonuç olarak uygulanan programın nicel ve nitel bulgularının birbirini desteklediği görülmektedir.

Kişileraras1 duygu düzenleme psikoeğitim programı bir devlet üniversitesinin eğitim fakültesi öğrencileri üzerinde sınırlı sayıda bir gruba uygulanmıştır. Elde edilen sonuçlar bu çalışma grubu ile sınırlıdır. Dolayısıyla sonraki araştırmalarda ergenler, yetişkinler gibi farklı ve daha geniş çalışma gruplarında yapılacak uygulamalar alanyazına zenginlik sağlayacaktır. Yine kişilerarası duygu düzenleme psikoeğitim programının sosyal destek, depresyon, stresle başa çıkma, kaygı bozuklukları, bağlanma stilleri gibi farklı değişkenlerle ilişkisi ve bu değişkenler üzerindeki etkisi de araştırmaya değer yeni çalışma konuları olacaktır. Deneysel sürecin geçerliliği ve güvenirliğini desteklemek için bundan sonraki çalışmalarda mülakat, odak grup görüşmesi gibi tekniklerle sürece ilişkin daha derinlemesine bilgi edinilebilir. Süreçte altı ay ve bir yıl gibi aralıklarla izleme çalışması yapılabilir ve programın kalıcılığına ilişkin elde edilen bulgular değerlendirilebilir. Bu çalışma yarı deneysel desende tasarlanmıştır. Daha sonraki çalışmalarda daha güçlü deneysel desenler kullanılarak programın etkililiği incelenebilir. Bununla birlikte kişiler arası duygu düzenleme psikoeğitim programı dört temel stratejiyi temel alarak sekiz oturumda gerçekleştirilmiştir. Sonraki çalışmalar için etkinliklerle birlikte oturum sayısı artırılarak zenginleştirilebilir. Bu çalışmada psikoeğitim programı kişilerarası duygu düzenleme yaklaşımı çerçevesinde hazırlanmıştır. Bu yaklaşım sonraki çalışmalarda farklı kuramlarla bütünleştirilerek daha farklı eğitim programları hazırlanabilir.

Kişilerarası duygu düzenleme yaklaşımına dayalı geliştirilen grup psikoeğitim programı bu kuramsal temelde hazırlanan alandaki ilk çalışma niteliğindedir. Bu araştırmanın gerek nicel gerekse nitel bulguları, kişilerarası psikoeğitim programının beliren yetişkinlerin duygu düzenleme becerisi üzerinde anlamlı bir etki yaptığı ve bu etkinin izleme testinde de devam ettiğini göstermiştir.

\section{Kaynakça}

Büyüköztürk, Ş. (2001). Deneysel desenler: Öntest-sontest kontrol grubu, desen ve veri analizi. Ankara: Pegem Akademi.

Coan, J. A. (2011). The Social Regulation of Emotion. In J. Decety \& J. T. Cacioppo (Eds.), The Oxford Handbook of Social Neuroscience: Oxford University Press.

Cohen, J. (2013). Statistical power analysis for the behavioral sciences. Academic press.

Creswell, J. W., Fetters, M. D., Plano Clark, V. L., \& Morales, A. (2009). Mixed Methods Intervention Trials. In Mixed Methods Research for Nursing and the Health Sciences (pp. 159180). John Wiley and Sons. https://doi.org/10.1002/9781444316490.ch9

Çelik, H., \& Kocabıyık, O. O. (2014). Genç yetişkinlerin saldırganlık ifade biçimlerinin cinsiyet ve bilişsel duygu düzenleme tarzları bağlamında incelenmesi. Trakya Üniversitesi Eğitim Fakültesi Dergisi, 4(1), 139-155.

Debrot, A., Schoebi, D., Perrez, M., \& Horn, A. B. (2013). Touch as an interpersonal emotion regulation process in couples' daily lives: The mediating role of psychological intimacy. Personality and Social Psychology Bulletin, 39(10), 1373-1385. 
Demir, V., \& Gündoğan, N. (2018). Bilinçli Farkındalık Temelli Bilişsel Terapi Programının Üniversite Öğrencilerinin Duygu Düzenleme Güçlüklerini Azaltmadaki Etkisi. Ege Eğitim Dergisi. 19(1), 46 - 66.

Ekman, P., Friesen, W. V., \& Ellsworth, P. (2013). Emotion in the human face: Guidelines for research and an integration of findings. USA, New York: Elsevier.

Gökdağ, C., Sorias, O., Kıran, S., \& Ger, S. (2019). Kişilerarası Duygu Düzenleme Ölçeğinin Türkçeye Uyarlanması ve Psikometrik Özelliklerinin İncelenmesi. Turk Psikiyatri Dergisi, 30(1), 57-66.

Greenberg, L. S. (2004). Emotion-focused therapy. Clinical Psychology \& Psychotherapy: An International Journal of Theory \& Practice, 11(1), 3-16.

Gross, J. J. (1998). The emerging field of emotion regulation: An integrative review. Review of General Psychology, 2 (3), 271-299.

Gross, J. J. (1999). Emotion regulation: Past, present, future. Cognition\&emotion, 13(5), 551-573.

Gross, J. J., \& John, O. P. (2003). Individual differences in two emotion regulation processes: implications for affect, relationships, and well-being. Journal of Personality and Social Psychology, 85(2), 348.

Gross, J. J., \& Thompson, R. A. (2007). Emotion regulation: Conceptual foundations. In J.J. Gross (Eds.), Handbook of Emotion Regulation, (pp.3-26). USA, New York: Guilford Press.

Gülgez, Ö., \& Gündüz, B. (2015). Diyalektik Davranış Terapisi Temelli Duygu Düzenleme Programının Üniversite Öğrencilerinin Duygu Düzenleme Güçlüklerini Azaltmadaki Etkisi. Çukurova University Faculty of Education Journal, 44(2) 191-208.

Higgins, E. T., \& Pittman, T. S. (2008). Motives of the human animal: Comprehending, managing, and sharing inner states. Annu. Rev. Psychol., 59, 361-385.

Hofmann, S. G. (2014). Interpersonal emotion regulation model of mood and anxiety disorders. Cognitive Therapy and Research, 38(5), 483-492.

Hofmann, S. G., Carpenter, J. K., \& Curtiss, J. (2016). Interpersonal emotion regulation questionnaire (IERQ): Scale development and psychometric characteristics. Cognitive Therapy and Research, 40(3), 341-356.

İşgören, G. (2018). Genç erişkinlerde bilişsel duygu düzenlemenin mükemmelliyetçilik ve depresyon ilişskisindeki rolü. (Yayımlanmamış Yüksek Lisans Tezi, Işık Üniversitesi, Sosyal Bilimler Enstitüsü). http://tez2.yok.gov.tr/ adresinden edinilmiştir.

Koç, M. S., Aka, B. T., Doğruyol, B., Curtiss, J., Carpenter, J. K., \& Hofmann, S. G. (2019). Psychometric properties of the Turkish version of the interpersonal emotion regulation questionnaire (IERQ). Journal of Psychopathology and Behavioral Assessment, 41(2), 294303.

Karasu, R. Ö. (2020). Ebeveyn kabul reddi ve kişilerarası duygu düzenleme stratejileri ile sosyal kaygı arasındaki ilişkilerin incelenmesi (Yayımlanmamış Yüksek Lisans Tezi, Maltepe Üniversitesi, Lisansüstü Eğitim Enstitüsü). http://tez2.yok.gov.tr/ adresinden edinilmiştir.

Kuzucu, Y. (2006). Duygularl fark etmeye ve ifade etmeye yönelik bir psikoeğitim programının, üniversite ögrencilerinin duygusal farkındalık düzeylerine, duygulart ifade etme eğilimlerine, psikolojik ve öznel iyi oluşlarına etkisi. (Yayınlanmamış Doktora Tezi, Ankara Üniversitesi Eğitim Bilimleri Enstitüsü). http://tez2.yok.gov.tr/ adresinden edinilmiştir.

Lazarus, R. S. (1993). From psychological stress to the emotions: A history of changing outlooks. Annual Review of Psychology, 44(1), 1-22.

Leahy, R. L., Tirch, D., \& Napolitano, L. A. (2011). Emotion regulation in psychotherapy: A practitioner's guide. USA, New York: The Guilford Press. 
Linehan, M. M. (1993). Skills training manual for treating borderline personality disorder. London: The Guilford Press.

Markus, H. R., \& Kitayama, S. (1991). Culture and the self: Implications for cognition, emotion, and motivation. Psychological Review, 98(2), 224.

Marroquín, B. (2011). Interpersonal emotion regulation as a mechanism of social support in depression. Clinical psychology review, 31(8), 1276-1290.

Monat, A., \& Lazarus, R. S. (Eds.). (1991). Stress and coping: An anthology. New York: Columbia University Press.

Preece, D. A., Becerra, R., Robinson, K., Dandy, J., \& Allan, A. (2018). Measuring emotion regulation ability across negative and positive emotions: The Perth Emotion Regulation Competency Inventory (PERCI). Personality and Individual Differences, 135, 229-241.

Rimé, B., Finkenauer, C., Luminet, O., Zech, E., \& Philippot, P. (1998). Social sharing of emotion: New evidence and new questions. European Review of Social Psychology, 9(1), 145-189.

Sarıcaoğlu, Ö. A (2020). Kişilerarası Duygu Düzenleme Ölçeği'nin Türkçeye Uyarlanması. I. International Congress of Pedagogical Research. Düzce 24 - 26 Haziran, Türkiye.

Saruhan, V., Başman, M., \& Ekşi, H. (2019). Kişilerarası Duygu Düzenleme Ölçeği'nin Türkçe'ye Uyarlanmas1. Abant İzzet Baysal Üniversitesi Eğitim Fakültesi Dergisi, 19 (3), 1090-1101. DOI: 10.17240/aibuefd.2019.19.49440-493921

Shaver, P. R., \& Mikulincer, M. (2007). Adult attachment strategies and the regulation of emotion. Handbook of Emotion Regulation, 446, 465.

Şahin, F. (1997). Grupla iletişim becerileri eğitiminin üniversite öğrencilerinin iletişim beceri düzeylerine etkisi. (Yayımlanmamış doktora tezi, Gazi Üniversitesi, Ankara). http://tez2.yok.gov.tr/ adresinden edinilmiştir.

Şahin, N. H., \& Durak, A. (1994). Kısa semptom envanteri (Brief symptom inventory-BSI). Türk gençleri için uyarlanması, Türk Psikoloji Dergisi, 9(31), 44-56.

Tarımtay, F. (2017). Attachment and marital adjustment: The mediating role of interpersonal emotion regulation. (Yayımlanmamış Yüksek Lisans Tezi, Bahçeşehir Üniversitesi, Sosyal Bilimler Enstitüsü). http://tez2.yok.gov.tr/ adresinden edinilmiştir.

Thompson, R. A. (1994). Emotion regulation: A theme in search of definition. Monographs of the society for research in child development, 59(2-3), 25-52.

Uyarağalar, T. (2019). The mediating role of interpersonal and intrapersonal emotion regulation in relation to early maladaptive schemas and social anxiety symptoms. (Yayımlanmamış Yüksek Lisans Tezi, Bahçeşehir Üniversitesi, Sosyal Bilimler Enstitüsü). http://tez2.yok.gov.tr/ adresinden edinilmiştir.

Vatan, S. (2020). Duygu düzenleme eğitiminin duygu düzenleme becerileri üzerindeki etkisinin incelenmesi. Anadolu Psikiyatri Dergisi, 21(4), 396-402.

Yalom, I. (1995). Grup psikoterapisinin teori ve pratiği (Çev. A Tangör, Ö Karaçam). İstanbul: Kabalcı Yayınevi.

Yıldırım, A., \& Şimşek, H. (2013). Sosyal bilimlerde nitel araştırma yöntemleri. Seçkin yayıncılık.

Zaki, J., \& Williams, W. C. (2013). Interpersonal emotion regulation. Emotion, 13(5), 803.

\section{Extended Abstract}

\section{Introduction}

Emotions are not regulated independently from people, on the contrary, emotion regulation process takes place with important social networks and social interaction that surround the individual throughout life. Interpersonal emotion regulation emphasizes the importance of social relationships in 
experiencing and expressing emotions. Zaki and Williams (2013) tried to determine which regulation strategies individuals use according to which interpersonal situations while regulating their own or others' emotions. The aim of this study is to investigate the effect of group psychoeducation program based on Interpersonal Emotion Regulation approach on interpersonal emotion regulation skills of university students.

\section{Methodology}

In this study, embedded design, one of the mixed research methods, was used. In embedded design, qualitative method is included in the design primarily to test the experimental program and support the quantitative method designed in this context (Creswell, Fetters, Plano Clark, \& Morales, 2009). A qualitative research design was added to support quantitative data within the quantitative research designed in experimental design. In this study, qualitative data collection method in the posttest measurement for the experimental group was embedded in the quantitative pre-test, post-test, followup test quasi-experimental design to examine the effectiveness of the group psychoeducation program developed based on the interpersonal emotion regulation approach. Eight-session group psychoeducation program was applied to the students in the experimental group and no intervention was made to the students in the control group. While the experimental group was given quantitative and qualitative data collection instruments before and after the experiment, the control group was given only quantitative data collection instruments. Additionally, in the follow-up test, quantitative data collection method was used in the experimental group. The study group consisted 18 university students: 9 in the experimental group and 9 in the control group. The data of the study were collected through personal information form, Interpersonal Emotion Regulation Scale (IERS) and group psychoeducation evaluation form.

\section{Findings and Discussion}

The findings of the study showed that the scores of the experimental group were significantly higher than the control group in terms of post-test scores from all dimensions of the IERS. This effect is longterm in the experimental group. The qualitative findings of the study show that the applied group psychoeducation program improves the students' interpersonal emotion regulation skills, as well as empathy and interpersonal communication skills. Hofmann (2014) also emphasizes the importance of social relationships in experiencing and expressing emotions. In this context, it is seen that the psychoeducation program based on the expression of emotions, emotion awareness, emotion regulation processes and awareness, and awareness of interpersonal emotion regulation helps emerging adults to express their interpersonal feelings. It is consistent with the findings of experimental studies conducted to increase emotion regulation strategies and communication skills of emerging adults (Gülgez \& Gündüz, 2015; Şahin, 1997). In this study, prepared psychoeducation program forms the core concept of interpersonal emotion regulation and the model has not been tested experimentally except the scale adaptation studies in Turkey. The group psychoeducation program developed based on the interpersonal emotion regulation approach is the first study in the field prepared on this theoretical basis. Both quantitative and qualitative findings of this study showed that the interpersonal psychoeducation program had a significant effect on the emotion regulation skills of emerging adults and this effect continued in the follow-up test.

*Bu makalede yazarların katkı oranları: Ayşe Özlem SARICAOĞLU \%60, Raşit AVCI \%40. 